\title{
A Russian National Idea and the International System
}

\section{Национальная идея России и международная система}

\author{
DOI: $10.12737 / 2587-6295-2021-5-3-75-96$ \\ УДК 327 \\ Received: 10.04.2021 Approved: 01.09.2021 Published: 25.09.2021
}

\section{Willerton J.P.}

Professor of Political Science, School of Government and Public Policy, University of Arizona, Tucson, USA.

e-mail:.jpw@arizona.edu

\section{Уиллертон Дж.П.}

Профессор политологии Школы государственного управления и государственной политики Университета Аризоны, Тусон, США.

e-mail:.jpw@arizona.edu

\section{Beznosov M.A.}

Lecturer, Department of Civic Engagement and Public Service, University of West Georgia, Carrollton, USA.

e-mail:mbeznosov@westga.edu

\section{Безносов М.А.}

Преподаватель кафедры гражданской активности и государственной службы Университета Западной Джорджии, Кэрроллтон, США.

e-mail: mbeznosov@westga.edu

\section{Carrier M.}

Curriculum Advisor, Lecturer, Faculty of Arts and Sciences, Department of Political Science, University of Montreal, Montreal, Canada.

e-mail: martin.carrier@umontreal.ca

\section{Карье М.}

Советник по учебной программе, преподаватель Департамента политологии Факультета искусств и наук Монреальского университета, Монреаль, Канада.

e-mail: martin.carrier@umontreal.ca

\begin{abstract}
Vladimir Putin and his governing team have operated out of a weltanschauung that offers a twenty first century Russian national idea that animates the Russian federal government's post-1999 policy program. This article explores the Russian national idea, illuminating the syndrome of pillars that comprise it, and tying the national idea to the Putin government's policy program. We apply an interdisciplinary case study approach, relying on a modified process tracing analysis, to identify the
\end{abstract}


national idea and its direct relevance to policy making. The notion of a Russian national idea has long preoccupied Russian intellectuals and even officials, and we focus on Vladimir Putin's thinking and the Putin team's actions as a national idea emerged and drives policies. Putin's Russian national idea is comprised of four pillars, the consolidated state, a functioning market economy, a re-established social welfare system, and Russia's return as a Eurasian leader. We understand these four pillars as constituting a syndrome, signifying that these four pillars reinforce one another. In this article, we give attention to the fourth, international, pillar of the twenty first century national idea. We consider the Russian Federation's return as a natural Eurasian leader, with a longer-term, historical notion of foreign policy honor that entails Russia's continued long-term commitment to Eastern Slavs and Eastern Orthodoxy. We link the notion of national honor with a contemporary consideration of a socalled Russian civilization that is relevant to both domestic and foreign policy interests. We highlight various policies, domestic and foreign, that are inherently related to this Russian national idea, and while we acknowledge a complex array of policy successes and dilemmas, we posit an overall Russian Federation programmatic advance. The theoretical significance of our article rests with its exploration of a regime's worldview and programmatic priorities in advancing policies intended to advance the society it governs. This article is guided by the judgment that the Russian national idea, as articulated by Putin and as applied in policies by the Putin team, merits our serious attention.

Keywords: Russian national idea, Putin policy program, Russian Eurasian policy, Russian foreign policy, Russian civilization, Honor in international relations, Eurasianism.

\section{Аннотация}

Владимир Путин и его правящая команда действовали и действуют в рамках мировоззрения, на основе которого была предложена российскому обществу национальная идея двадцать первого века, которая, в свою очередь, является базисом для формирования политической программы правительства Российской Федерации с 1999 г. В этой статье исследуется русская национальная идея, освещается синдром составляющих ее столпов, и национальная идея связывается с политической программой правительства Путина. Мы применяем междисииплинарный подход к тематическому исследованию, основанный на модифицированном анализе отслеживания процессов, чтобы определить национальную идею и ее прямое отношение к выработке политики. Национальная идея России уже долгое время занимает умы российских интеллектуалов и официальных лиц. Мы анализируем действия Владимира Путина и его команды в процессе возникновения национальной идеи и ее влияния на политику. Национальная идея России в интерпретации Путина состоит из четырех столпов: консолидированного государства, функционирующей рыночной экономики, воссозданной системы социального обеспечения и возвращения России к роли евразийского лидера. Мы понимаем эти четыре столпа как взаимоусиливающие друг друга. В работе мы рассматриваем четвертый, интернациональный столп национальной идеи двадцать первого века. Мы рассматриваем возвращение Российской Федерации в качестве естественного евразийского лидера с историческими представлениями о чести и о долге в формировании внешней политики, которые предполагают неизменную историческую приверженность России к восточнославянским народам и к православию. Мы связываем понятие национальной чести с современной трактовкой русской цивилизации, которая имеет отношение как к внутренним, так и к внешнеполитическим интересам. Мы выделяем различные политические меры, внутренние и внешние, которые по своей сути связаны с национальной идеей России. Признавая комплексный ряд политических успехов и дилемм, мы констатируем общий программный прогресс Российской Федерации. Теоретическая значимость нашей статьи заключается в 
исследовании мировоззрения режима и программных приоритетов в продвижении политики, направленной на развитие общества, которым он управляет. Мы утверждаем, что различные аспекты национальной идеи России, сформулированные Путиным и применяемые в деятельности его команды, заслуживают серьезного внимания со стороны обществоведов.

Ключевые слова: национальная идея России, политическая программа Путина, российская евразийская политика, российская внешняя политика, русская цивилизация, честь в международных отношениях, евразийство.

\section{Introduction}

This article explores the logic and substance of a Putin-promoted Russian national idea that undergirds the twenty first century programmatic efforts of the governing Putin team. Drawing upon both Russian and Western scholarship about both a Russian national self-concept and the Putin program to revive Russia after the Soviet collapse and «Time of Troubles», the article identifies a syndrome of four pillars that constitute a contemporary national idea. The article gives special attention to the fourth pillar, the international component of the national, with the notion of Russia as the natural Eurasian leader, a protector of Eastern Slavs and Eastern Orthodoxy, and a Russian civilization-state.

The grinding, long-term decline of the Soviet Union through the 1980s, culminating with the August 1991 coup d'état and subsequent political system collapse by December of that year, led to an emergent Russian Federation that struggled with a new idea of its collective national meaning and developmental direction. A push-pull of forces, both internal and external, overwhelmed the government and society. Contrasting perspectives looked to the Russian past, Medieval, Imperial, and Soviet, along with entertaining ideas and experiences from other nations, especially Western (e.g., France and Germany, with at best passing attention to the U.S.). Vladimir Putin has observed that reflection over a Russian national idea has been a long-term preoccupation of Russians, going back centuries ${ }^{1}$. This was certainly true as the 1990 s evolved. The pre-Soviet past offered communalcollective experience with localized assemblies and consultative bodies, the Soviet past reinforced the importance of social welfare obligations, while France had experience with a mixed presidentialparliamentary political system with the split executive (posts of president and prime minister), and Germany operated with an effective federal system balancing central and regional interests. Russia of the 1990s was consumed with transforming change, what we term a «quadruple revolution»; a quadruple revolution that simultaneously constituted root-and-branch political, economic, and societal change, while also seeking a new national identity [46]. Even granting all the powerful change affecting the entire Marxist-Leninist world in the wake of the Soviet collapse, no other country experienced the quadruple revolution. Yet arguably the most difficult and even perplexing revolution that rocked the Russian polity and society was the seeking of a new post-Soviet Russian national identity, what we term a Russian national idea. We address this national idea here, with focus on one of the four pillars that inform that Russian national idea: Russia's self-concept as a (perhaps the) natural Eurasian leader, and as tied with Russia serving as a long-time defender of Eastern Slavs and Eastern Orthodoxy.

A review of the centuries-long Russian engagement of a Russian national idea would yield a lengthy manuscript that would include numerous contrasting conceptions grounded in varied

\footnotetext{
${ }^{1}$ Vladimir Putin remarked, «Of course, we should always be thinking about the future. Here in Russia, we have this old tradition, a favourite pastime, of searching for a national idea. This is something akin to looking for the meaning of life. It is, generally speaking, a useful and interesting pursuit, and also one that is never-ending». URL: http://en.kremlin.ru/events/president/transcripts/24203. Accessed: 22.09.2021.
} 
weltanschauung. Our interest is in a more practical understanding of a $21^{\text {st }}$ century Russian national idea, and to this end we focus on the thinking and policy actions of the country's governing team and its leading figure, Vladimir Putin. More than twenty years of governance, with considerable policy challenge in all domains - political, economic, societal, and international - have yielded a programmatic record that is identifiable and not without significant developmental advance. The intent of this article is to illuminate the national idea and the consequent programmatic record. Interestingly, only weeks before unexpectedly rising to the Russian Presidency with the dramatic retirement of Boris Yeltsin, Vladimir Putin authored a high-profile article in Novaya gazeta in which he laid out the broad contours of a governmental program that would address the myriad challenges confronting the Russian state upon the dawn of the new millennium ${ }^{2}$. Evaluated from the vantage point of the more than two decades of Putin team governance since that 1999 publication, one can see the broad contours of the government's program that were set out. This article draws upon that 1999 article, factoring in elaborations from subsequent public addresses and utterances to identify the four central pillars of a Putin-articulated Russian national idea, with those four components at the heart of our analysis of a guiding Russian national idea of the 2020s. Three decades after the Soviet collapse, there is a distinguishable Russian national idea that can be tied with the more than two-decade-long Putin policy program, the national idea merits our attention, and we highlight one of its four components - Russia as Eurasian leader - in this article ${ }^{3}$.

\section{Brief Literature Review and Methodology}

If, as Vladimir Putin has mused, Russians have long given attention to a national idea, with a good number of philosophical, literary, and scholarly works engaging this mammoth topic, there is surprisingly little significant Western scholarship on a Russian national idea. There are classic studies, for instance James Billington's monumental tome [31] and Hugh Ragsdale's thematic analysis [41], but these volumes offer long-term historical takes that only set a foundation for appreciating twenty first century thinking and developments. Meanwhile, contemporary works engaging the Putin team and its programmatic record often present spirited illumination of twenty first century Russian authoritarianism and corrupt elite politics, with little or no attention to the thinking that underlies the regime's domestic program and goals. If policies and goals are discussed, attention falls on matters of elite power, public suppression, and neo-authoritarianism. Some volumes offer a more detailed look at the policy specifics of a renewed Russian authoritarian polity [42]. Others take a comprehensive, cross-national look that places Putin's Russia solidly in the ranks of $21^{\text {st }}$ century authoritarian polities $[27,37]$. Our broader research project and this article are intended to build on this Western scholarly reality, guided by the historical-cultural studies of the past, while seeking to fill a void in the contemporary scholarship.

Our efforts are significantly helped by the more voluminous Russian scholarship, which spans the philosophical, literary, and intellectual, to include modern Russian political observers and actors. Important foundational reflections on the national idea were offered by such important figures as N.A. Berdyaev, N.Y. Danilevsky, and I.A. Ilyin [2, 5, 7]. As this literature developed, others illuminated major provisions of the national idea that were tied with an interpretation of various problems tied with Russia's civilizational and cultural identity; the Russian national idea developed with such concepts as collegiality (unity in the magnitude), total unity, solidarity, eschatology, social justice, and the preeminence of spiritual and moral values over material values (non-acquisitiveness) $[10,18,22]$.

\footnotetext{
${ }^{2}$ URL: https://pages.uoregon.edu/kimball/Putin.htm. Accessed: 22.09.2021.

${ }^{3}$ We develop all four of the components of a Putin Team Russian national idea in a book manuscript we are currently completing, «Vladimir Putin and Russia’s Search for a National Idea».
} 
These and other writers also elaborated on the geographical and historical factors underlying the civilizational and cultural development of the Russian nation [5, 7, 10, 18].

Within the Marxist-Leninist framework, the place of the national idea in scholarly research was given to ideology. Much could be discussed here, but we simply note the position and role of ideology for the state and official thinking, with the principles and content of the official ideology offering a class analysis that superseded matters of national-cultural identity. It was only at the end of the 20th century that an active discussion about the essence of the Russian national idea reemerged in Russia [15]. As a result of intense intellectual-scholarly discussions, opposing points of view emerged. Representatives of a national-patriotic trend advocated the revival of the Russian idea, while supporters of a liberal ideology assessed it as archaic and devoid of potential in modern conditions. These discussions were only further invigorated by President Boris Yeltsin's call for the creation of a national idea, with a high-profile work, entitled «Russia in search of an idea», edited by G. Satarov, and including a variety of Russian political strategists, attempting to formulate the Russian national idea as a kind of «civic religion» [21].

In modern Russian scholarly discourse there is no unambiguous approach to the concept of national idea, but the range of opinions is wide, extending from considerable skepticism [19] to the formulation of detailed conceptual formulas [13]. Some rich discussion, in the tradition of a historiosophical approach is offered [16, 24], with intriguing insights offered through the comparative historical analysis of Russian and Western civilization [14]. Concerns with ideology also returned to scholarly discourse, with non-classical interpretations of the national idea becoming more popular, the national idea's integrative function coming to the fore. Overall, despite significant achievements in the development of various facets of the national idea, in the modern Russian socio-political literature, the understanding of the national idea is conceptually fragmented, and it lacks a holistic approach ${ }^{4}$.

The methodological approach of this paper is based on a combination of various scientific methods. Our use of general scientific methods (e.g., systemic analysis and historical analysis) allows us to characterize the concepts of the international system, Russian foreign policy, and the Russian national idea and study these concepts in interrelation. We use an interdisciplinary case study approach for gathering empirical data. Our goal is a more exhaustive study of the numerous relationships and interdependencies that characterize various elements of the Russian national idea. Meanwhile, a casestudy design for our research allows us to identify causal relationships and analyze in their entirety the mechanisms of occurrence, functioning, and further development of Russian national idea. More specifically, we have applied a modified process tracing approach [30] wherein we have developed the components of the national idea, looking back through evolving Russian thought and experience, with passing reference to Western thought and experience. As we apply a combined historical analytical and process tracing approach to our efforts, we especially draw upon a content analysis of speeches by prominent contemporary Russian politicians and public figures, with special attention to Vladimir Putin. As Russia's «paramount leader» and leading architect of the country's policy program, our analysis is grounded in careful analysis of a goodly number of Putin's most important policy pronouncements, beginning with his high-profile December 1999 Novaya gazeta essay, including important official presentations (e.g., state of the nation addresses), high-visibility appearances (e.g.,

\footnotetext{
${ }^{4}$ One of the interesting results of modern research on issues related to the national idea is a collective monograph, developed at the Center for Problem Analysis and Public Administration Design, and edited by the Center's council consisting of V.I. Yakunin, S.S. Sulakshin, V.E. Bagdasaryan, M.V. Vilisov, S.G. Kara-Murza, V.N. Lexin. It offers an interesting discourse of a multidisciplinary scientific approach, which reflects, on the one hand, the modern fact of the mandatory fixation of the national idea in the regulatory legal acts of the state, and on the other, its reflective variability [26].
} 
meetings with the Valdai Discussion Club), and including position papers of his election campaigns (e.g., the position papers of January-February 2012). Other prominent figures (e.g., Dmitry Medvedev, Sergei Lavrov, and the two Patriarchs of the Russian Orthodox Church) have also shared comments relevant to a Russian national idea, and they merit our attention. 


\section{A Putin team Russian national idea}

We contend that the national idea for a flourishing Russia, as set out by Vladimir Putin and his governing team, is grounded in four overriding pillars of the post-1999, $21^{\text {st }}$ century, Russian reality: construction of (1) a powerful state, (2) a functioning market economy guided by that powerful state, (3) a social justice, or social welfare, political system that provides a safety net to the country's population, and (4) a foreign-security policy that advances Russia's position as a Eurasian leader, and as defender of Eastern Slavs and Eastern Orthodoxy. We understand these four pillars as constituting a syndrome of interconnected elements, with the assumption of the strong state as the overriding core pillar of these interconnected and self-reinforcing structural and policy factors. Our illumination of the fourth pillar, involving Russia's geostrategic position and external interests, necessarily must be grounded in the first three pillars, all of them domestic, and all setting in place a consolidated and reliable internal reality that is necessary for Russia to assume its Eurasian position and to project its interests. We briefly discuss these three domestic pillars here, providing the context needed to appreciate that fourth - international - pillar of the national idea.

Consolidation of the strong state that can tackle the wide array of political, economic, and societal tasks that confront the contemporary polity is the core principle of the Russian national idea advanced by Vladimir Putin and his team. Indeed, without the viable and assertive state, none of the other three central pillars of the national idea, spanning both the domestic and foreign policy settings, can be accomplished.

The consolidation of a strong state as the central condition for a national vision might seem unexceptionable and hardly noteworthy in a Russia that had survived the Soviet collapse nearly a decade before Putin came to power. But, in fact, the challenges of a decade commonly termed by Russians as a «time of troubles», overwhelmed by a «failing state» that had struggled to meet even the most basic obligations of the 1994 Yeltsin Constitution, were the daunting reality that confronted Putin when he unexpectedly assumed power January 1, $2000[3,11,12,17]$. Re-tooling state institutions was a necessary action for the new leader in tacking an efficient government that was not only lacking elite and public respect, but that was incapable of generating needed sociopolitical norms and trust. Many, especially Western, observers understandably concentrate on the numerous liberalization and democratization shortcomings of the Putin team's approach to state consolidation [29, 40, 49]; our assessment of Putin team state consolidation efforts does not focus on - or evaluate - such liberalization and democracy-building shortcomings. Our contention is that whatever the implications for long-term Russian democratization, the Putin team pursued an intentional strategy of re-positioning the Russian federal state as the key institution for national socio-economic development and restoration of the country's international position. The democratic nature of the strengthened state is a separate matter from that of a consolidated state that can fulfill the policy intentions of the elite and society, whether set out in the constitution and other fundamental documents, or in the policy initiatives set out by the governing regime.

We cannot develop in detail the numerous important institutional, policy, and even personnel developments of the Putin government to fully develop the logic of the consolidated federal state, but one suggestive observation merits attention. In the various efforts to consolidate the Russian state, Putin - as the country's «paramount leader» - showed himself to be a transactional leader; a politician whose leadership style revealed flexibility and a willingness to engage in trial-and-error efforts to advance longer-term ends in consolidation of the state and promotion of his policy program ${ }^{5}$. Several

\footnotetext{
${ }^{5}$ By the term «paramount leader», we mean that Vladimir Putin has enjoyed a position of tremendous power that transcends his official position, with that power grounded in his reputation among most elites and the citizenry as a decisive
} 
high-priority policies oriented toward state consolidation were offered as initiatives that could evolve over time and could be tweaked or more seriously altered as circumstances warranted. Thus, the allimportant 2000 flat tax initiative, simple in design and easily understood by all, was presented, with its identifiable limitations, as a needed first effort, but one open to likely change as Russia, long-term, would likely move toward a progressive tax system. Likewise, institutional reforms around the selection of regional governors were presented as being, in nature, transitional, and these processes indeed were altered with a return to the direct election of governors within a decade. Overall, the fundamental principles and basic institutional arrangements of the 1994 Yeltsin Constitution remained intact as the Putin regime evolved. But occasional tinkering with specific institutions, including the composition of the federal executive and facets of the federal presidency, continued through the various presidencies of the Putin period ${ }^{6}$.

Second, ensuring the successful functioning of a productive market economy is the second of the four pillars of the Putin-promoted Russian national idea. Such an economy is achieved through the consolidated state, and that economy must be succeeding to realize the remaining two factors of the idea: the desired social justice ends, and the restoration of Russia as at least a Eurasian regional power. Putin has been clear that he does not support a return to the Soviet command economy, though his team's policies demonstrate a commitment to bolstering the position of the consolidated state in directing and resurrecting an economy severely weakened by the Soviet collapse and the subsequent chaotic, «Wild West», 1990s ${ }^{7}$. Putin's national idea embraces the centrality of stable supply-demand relations in ensuring economic growth and societal revival. But of overriding importance in reviving a productive economy, albeit with a Western-style market, is the assumption of a sovereign and independent Russian polity whose economic logic and functioning are not set by foreign interests (especially through foreign investments), or by domestic powerful business interests (i.e., oligarchs) who hoard resources and even move them abroad as suits their parochial ends. These problematic foreign and domestic financial-economic realities overwhelmed Russia of the pre-Putin 1990s, with a then-weak state unable, or its officials unwilling, to fundamentally transform this reality ${ }^{8}$. Establishing a productive and growing domestic market has been a core policy goal of all Putin period governments.

Again, we cannot develop in detail the complex and important initiatives of the Putin period that have helped further develop the Russian regulated market economy, but suffice it to note that development required building a state capacity capable of achieving (1) low inflation ${ }^{9}$, (2) low government deficits ${ }^{10}$, (3) stabilized domestic supply-demand realities, (4) viable banks and financial

leader who delivers on the policies he puts forward. Even during the important Dmitry Medvedev presidency of 2008-12, Putin's position as a paramount leader was widely understood, albeit he held the second position in the federal executive.

${ }^{6}$ Especially important institutional changes involved the 2020 Constitutional reforms, including the reorganization of the State Council as an advisory body, designed to serve as an executive institutional counterpart to the Federation Council.

${ }^{7}$ Putin memorably commented during a call-in radio program in February 2000, just months into his acting presidency, «Anyone who does not miss the Soviet Union, does not have a heart; anyone who wants the Soviet Union back, does not have a brain». URL: https://ria.ru/20050505/39937603.html. Accessed: 22.09.2021.

${ }^{8}$ Symbolic of this 1990 s reality was the position and influence of Russia's then-richest oligarch, Boris Berezovsky, whose business interests were vast, had close ties with President Yeltsin, and came to serve as the head of the Commonwealth of Independent States (CIS) in the later 1990s.

${ }^{9}$ «Vladimir Putin drew attention to the dramatic drop in Russia's inflation rate compared to the 1990s. In 1992 the inflation rate was 2,600 points, in 1999 it was at the level of 35-36, and now this figure is «in the region of three». URL: https://aif.ru/money/economy/putin_rasskazal_ob_ekonomicheskom_razvitii_rossii_za_20_let. Accessed: 22.09.2021.

${ }^{10}$ The debt-to-GDP ratio remains one of the lowest in the world - it remained at $1 \overline{3}-1 \overline{4} \%$ until 2020 . At the same time, the average level of debt-to-GDP ratio for developed economies in 2019 was $103.8 \%$, and for developing economies $-54.7 \%$. URL: https://www.raexpert.ru/researches/public_debt_2021/. Accessed: 22.09.2021. 
institutions $^{11}$, while (5) reining in the worst facets of the country's widespread corruption ${ }^{12}$. Meanwhile, harnessing traditional economic industries (e.g., natural resources, machinery and machine tools, and transportation) and transforming agriculture (and even making it a focus of export efforts) were core to an over-20-year effort that witnessed Russian Gross Domestic Product (as measured in purchasing parity power) move from being the world's tenth largest national economy at $\$ 1.4$ trillion (1999) to sixth largest at $\$ 4.3$ trillion (2021 estimate) ${ }^{13}$.

Finally, partially reflecting the long Russian collectivist-communalist tradition, and also factoring in more modern Russians' positive assessments of social justice ends realized in Nordic and Northern European countries, commitment to (re)instating a social welfare system is a third pillar of the Putin and governing team's national idea. The Russian state had long assumed the role as the primary protector of general public interests; this is at the heart of what Russians call sotsial'naya spravadlivost' (social justice). Long-time Russian societal-cultural norms, including sobornost' (societal spiritual unity) ${ }^{14}$, the obshchina (self-governing community), and even the notion of the peasant mir (land-defined peasant collective) had reinforced the idea of a societal solidarity that encouraged a community consciousness and sense of responsibility [35]. In the pre-Soviet $19^{\text {th }}$ century, it had fallen on the Russian Orthodox Church, joined with the bureaucratized state, to address public social welfare needs, with the later $19^{\text {th }}$ century educational reforms of the Emperor Alexander II fundamentally expanding the state's involvement and sense of responsibility into that domain. The Soviet system built on these traditional norms, with an ever-more powerful (and intrusive) state promoting a modernization program that emphasized not just electrification and industrialization but universal literacy ${ }^{15}$. Soviet values were very much focused on the notion of a common citizen sense of community, the creation of a «Soviet people», with an emphasis on what was termed «vzaimopomoshch» (mutual assistance) [20]. Meanwhile, Soviet period constitutions, including the 1936 Stalin Constitution and 1977 Brezhnev Constitution, set out for the citizen a wide array of material or «quality of life» rights, looking beyond education to include healthcare, housing, maternity support, and eldercare. Most of these substantive rights were gone with the 1993 Yeltsin Constitution, as postSoviet Russia embraced the new socioeconomic conditions of a market system that would not generate the resources to award such social welfare guarantees ${ }^{16}$.

Social welfare, social justice, guarantees of the national idea could only be addressed as the economy revived and as the state collected the revenues necessary to underwrite revived education and healthcare citizen rights. The state consolidation of the first Putin presidential term (2000-2004), including fiscal reforms and a new tax policy, were required preconditions for the National Priority

\footnotetext{
${ }^{11}$ Space precludes a discussion of the Putin team efforts to stabilize and normalize financial transactions, build reliable banks, and bolster domestic and foreign assessments of the banking system's reliability. For instance, Sberbank, as a state monopoly, has emerged as a global lending bank (e.g., in digitalization).

${ }^{12}$ One suggestive, under-the-radar, but important, effort to rein in corruption efforts from outside the country involved the 2008 creation of the Russian Commission on Monitoring Foreign Investment, chaired by Dmitry Medvedev, and which has supervised the investment of over $\$ 6.8$ billion in strategic domestic industries.

${ }^{13}$ See the International Monetary Fund, "GDP PPP: Report for Selected Countries and Subjects," 2021, and the IMF Dababase, both retrieved 29 June 2021. Between 1999 and 2021, Russia's overall economy, as measured by GDP PPP, passed up those of Brazil, France, Italy, and the UK, while closing the gap with Germany; URL: https://www.imf.org/en/Publications/WEO/weo-database/2021/April. Accessed: 22.09.2021.

${ }^{14}$ It is important to add that sobornost' is fundamentally antithetical to individualism.

${ }^{15}$ According to the 1897 Census, roughly $28.4 \%$ of Imperial Russian citizens were literate. It is estimated that universal literacy was achieved sometime in the 1950s.

${ }^{16}$ Thus, for instance, where the Soviet system had proudly guaranteed every citizen the right to work, the new post-Soviet system guaranteed creating the economic conditions wherein the citizen could find work. The 1993 Yeltsin Constitution did not explicitly promote sotsial'naya spravadlivost'.
} 
Projects (i.e., agriculture, education, healthcare, and housing) and even the Stabilization Fund (i.e., budgetary "rainy day» fund) leading into the second Putin presidential term (these initiatives launched and consolidated in the period 2003-2005). The overtime monetary value of these projects and the stabilization summed to hundreds of millions of US dollars, and were critical to significant programmatic and policy achievements measurable by the Medvedev (2008-2012) and second Putin (commencing in 2012) presidencies ${ }^{17}$. Indeed, reinvestment in socioeconomic programs tied with social justice goals grew in the second Putin presidency, especially 4-5 years after the 2014 UkraineCrimea crisis, the early imposition of Western sanctions, and the important drop in world market prices for fossil fuels. Meanwhile, related policy promises of the early second Putin presidency (i.e., the so-called «May Directives» of 2012), put off by the drop in government revenues stemming from the country's economic decline related to Ukraine-Crimea-sanctions-oil prices, were resurrected in the Putin second presidency second terms (commencing in 2018). Significant increased support for families through childcare allowances, relaxed arrangements for house mortgages were matched with additional political-legal guarantees embedded in the summer 2020 constitutional reforms (e.g., guaranteed minimum wages and indexation of pensions).

This important social welfare pillar, joined with the very important consolidation of the state pillar and functioning market pillar, form the domestic foundation for a fourth, international, pillar of Russia as Eurasian leader. We develop in more detail this fourth pillar, understanding that Russia's return from the «Time of Troubles» of the 1990s, with an interrelated set of domestic political, economic, and societal policies and consequent advance, would be essential for Russia's emergence as a Eurasian actor of consequence.

\section{Reemergence of Russia as «natural» Eurasian leader}

If the Russian national idea is fully grounded in a set of interconnected domestic arrangements, political, economic, and societal, the national idea is also embedded in a broader regional and global context within which Russia operates as a regional - and even global - leader [45]. Such an embeddedness is not only a value core to the $21^{\text {st }}$ century notion of the national idea, but it is rooted in values and preferences found in both the Imperial and Soviet Russian past [1, 2, 6, 8, 25]. Vladimir Putin and his team not only set out a multifaceted understanding of a national idea consonant with contemporary $21^{\text {st }}$ century circumstances and elite and public preferences. Putin and his team build off of a historical past, extending back at least 200 years, wherein a strong, confident Russian state operates assertively within the Eurasian setting in which it is an active and influential actor. The confident Russian state also functions as the defender of Eastern Slavs, and the defender of Russian Orthodoxy, albeit with challenges to such a desired position coming from different quarters.

Many concerns underlay Russia's approach to its positioning in Eurasia and its relations with neighboring states, not the least grounded in reinforcing Russia's security (whether through pliable buffer zones or military alliances) or in furthering Russia's economic-trading interests ${ }^{18}$. We cannot fully assess or evaluate a rich array of calculations, actions, and results of Imperial Russian and Soviet foreign-security policy intentions, which others have well-evaluated. As we consider a $21^{\text {st }}$ century Russian national idea, spearheaded by the over two-decade-governing Putin team, we consider a Russia that is endeavoring to reclaim a power position that was severely weakened by the Soviet collapse [46].

\footnotetext{
${ }^{17}$ Note the turnaround in long-term population decline, with increased birthrate figures, increased longevity of Russian men, and a stabilization fund that could continue to fund pensions in periods of economic contraction.

${ }^{18}$ URL: http://publication.pravo.gov.ru/Document/View/0001202107030001. Accessed: 22.09.2021.
} 
The condition of the Russian «failing state», to which we have already referred, must be nested in the power and policy challenges that inhere in the country's profoundly weakened external position. Late $20^{\text {th }}$ and $21^{\text {st }}$ century challenges to the Russian Federation not involved the countries of the FSU (former Soviet Union), but also Central-East European and Asian (e.g., Mongolia) countries that had been Soviet period allies. Important challenges have been tied with other global and regional powers, including the U.S., Germany and France (and as E.U. leaders), China, and Turkey. Whatever President Boris Yeltsin's foreign policy preferences may have been, Russia assumed a generally accommodationist stance vis-à-vis power rivals in the 1990s [28]. It was only in March 1999, with NATO bombing of Serbia, and the dramatic turnaround of his U.S.-bound flight, that Russian Foreign Minister Yevgeny Primakov signaled open opposition to Western (especially American) actions in Russia's traditional sphere of influence ${ }^{19}$. Less than a year later, then-Prime Minister Vladimir Putin would set out a high-profile, wide-ranging policy position paper that would articulate many facets of an emergent Russian national idea, including a vision of Russia as a Eurasian leader ${ }^{20}$. And, in yet another dramatic development just weeks after the publication of that seminal paper, Putin would find himself acting president, with his team quickly consolidating power and moving on that Putin vision.

A profound dilemma for Russia in advancing its Eurasian dominance, even granting Russia's mounting power resources and related will to assert its interests, is the worldview and assumptions of the world's hegemonic power, the United States, in accepting some sort of Russian Eurasian leadership position [47, 48]. In the wake of the U.S.S.R.'s collapse, which the U.S. viewed as a Western (especially American) defeat of Soviet power, there was a concomitant expectation that the Russian Federation would accept a power position subordinate to that of the U.S., akin to what the U.S.'s WW II allies (e.g., Britain and France) and defeated enemies (e.g., Germany and Japan) had done decades earlier. It was expected that Russia would now «behave» in the post-Cold War world, accepting international formal and informal «rules of the game», dominant in the U.S.-led Western world. As Russia now joined Western (i.e., U.S.) crafted international organizations (IOs), its external power impulses would be channeled. In more concrete terms, Russia would accept states once a part of its alliance system or even part of the Russian Empire and Soviet Union joining international organizations that excluded Russia. These IOs most notably included the European Union and NATO.

Yet Russians did not understand the Soviet collapse and emergence of the Russian Federation as the result of some kind of defeat. Nor did Russians, even of the Yeltsin regime, accept some long-term secondary Eurasian power position, with Russian interests regionally and even globally subordinate to those of the U.S. In this fundamental - and profound - difference in understanding of the ending of the Cold War, and of the consequent global and Eurasian regional power arrangements, lies the fundamental reason for the growing and ever more acrimonious power rivalry that characterized Russian-American relations of the Putin period. The Russian national idea fully assumes an assertive and leading Eurasian power position for Russia, and thus this conceptual-ideological-policy construct only further legitimates a juxtaposing of Russia's interests vis-à-vis the U.S. Such an assertive posturing not only reflects the thinking of Putin when he addressed the Munich Security Conference in $2007^{21}$, it was equally evident in the reflections of former President Gorbachev more than a decade later [34].

From the period beginning in 1989, as Gorbachevian perestroika and foreign policy New Thinking accelerated, through to the 2020s, various concrete FSU, Central-East European, and Eurasian

19 «Петля Примакова»: Как разворот над Атлантикой вернул Россию на мировую арену. URL: https://ria.ru/20190323/1551983046.html. Accessed: 22.09.2021.

${ }^{20}$ See Note 2.

${ }^{21}$ URL: http://en.kremlin.ru/events/president/transcripts/24034; accessed 16.06.21. 
developments both challenged and reinforced the foreign-security policy logic of the Russian national idea. There was nothing Russia could do to forestall various Central-East European countries from realigning with the West, including through EU and NATO membership. Even before the formal collapse of the USSR, the three Baltic states had declared their independence, and would move as rapidly as possible to join the EU and NATO. Moldovan interest in possibly rejoining Romania and, hence, moving toward the West, precipitated Russian support for the breakaway Transdniestria, with even the pro-Western Russian Foreign Minister Andrei Kozyrev coming around to supporting Russian solidarity with the breakaway region. States of the Caucasus and Central Asia posed varying but equally complicated realities, with Russia better able to restore some semblance of its regional influence in some (e.g., Armenia, Kazakhstan, and Uzbekistan) than in others (e.g., Azerbaijan and Turkmenistan). Yet others (e.g., Georgia and Kyrgyzstan) would pose idiosyncratic challenges, which would, off-and-on, bedevil Moscow's efforts.

Of paramount importance in the articulation of a post-Soviet Russian national idea is the status of Ukraine and Belarus and the all-important relations of Russia with these two Eastern Slavic states. Any discussion of Russian-Ukrainian-Belarusian relations entails countless complexities and nuances that make any summary analysis here difficult. But certain overriding themes may be noted.

First, in the case of Ukraine, the word «state» rather than «nation» may be especially appropriate, as the $20^{\text {th }}$ and $21^{\text {st }}$ century Ukrainian state was essentially comprised of a number of nations, both geographically and culturally-ethnically determined, with the weltanschauung and interests of these intra-Ukrainian nations often counterpoised and even, occasionally, subject to conflict. With the exception of Leonid Kuchma, all post-Soviet Ukrainian presidents failed to guide the troubled polity and hold power, all being voted out of office - or, in the case of Viktor Yanukovych, who would surely have been defeated had he had the opportunity to run for reelection, overthrown in a coup d'état - after only one term in office ${ }^{22}$. Fragmented Ukraine had been «held together» and included in a powerful Russian state by a firm Imperial or Soviet hand. A centuries old domestic Ukrainian struggle to project a cultural-ethnic identity distinct from Russia's long bedeviled Russian rulers, while it confounded post-1991 Kiev leaders.

Second, the Russian understanding of a special and intense relationship with Ukraine has consistently overwhelmed the Russian polity and society, from Imperial to post-Soviet times. Kievan Rus' is the long-recognized font of the Russian civilization, and the area of Ukraine has long been a priority for Russian leaders and populace. Thus, the influential (liberal-turned-conservative) architect of mid-19 ${ }^{\text {th }}$ century Russian imperial education policy, Mikhail Katkov, could speak of the strong Russian love for Ukraine «in all her peculiarities», going on to describe as «odious» any effort to introduce a feeling of «mine and thine» into Russian-Ukrainian relations [36]. Nearly 150 years later, the popular $21^{\text {st }}$ century rapper Roma Zhigan would communicate the same sentiment - in similar phrasing - in a high-profile Russian nationalist music video, «Rossiya» ${ }^{23}$. The overthrow of the Yanukovych regime in February 2014, with the possibility of Ukraine joining the European Union, and Crimea and its Black Sea naval facilities becoming part of the NATO security system, rallied $90 \%$ or more of the Russian population in supporting action in Crimea and eastern Ukraine (Donbas) [38]. More than a decade before the dramatic events of 2014, long-time American Russia observer, George

\footnotetext{
${ }^{22}$ Kuchma was able to get re-elected in 1999 thanks to evident signs of economic growth by the time of the elections, as well as due to the fact that his major opponent, Pyotr Simonenko, was a prominent figure in the Communist Party of Ukraine, making him an easy target for «negative campaigning» by the country's oligarch-controlled mass media.

${ }^{23}$ In expressing his thanks for being Russian, Zhigan adds, «I sincerely love you with all my heart, you, Russia, Belarus, and Ukraine, and never will we be brought apart, we are united». URL: https://www.youtube.com/watch?v=yiYy9piawgY. Accessed: 22.09.2021.
} 
Kennan, would warn that any Western move into Ukraine in contravention of Russian interests would occasion a strong Russian response, and it did [39].

Meanwhile, if smaller in size with a population comparable to a Russian oblast, Belarus would hold comparable importance to both Russian elites and mass populace. The logic of post-Soviet Russian-Belarussian institutionalized linkages, going back to the 1996 Commonwealth and 1999 Union State, reveal the importance to both elites and peoples of a special relationship between the two polities, while there has been the absence of the antagonistic nationalistic push-pull of more complicated relations characterizing Russian-Ukrainian relations.

Andrei Tsygankov has provocatively - but we contend accurately - applied the notion of «honor» to the pursuit of Russian foreign policy, and in Tsygankov's understanding of the notion this pursuit has often characterized Russian actions since at least the beginning of the $19^{\text {th }}$ century [44]. The notion of a country's honor is very much tied to its national self-concept, in the Russian case that national self-concept being what we term the Russian national idea, and this connection transcends that country's domestic political system type and its power imperatives. Indeed, a country can pursue and safeguard its power interests through its self-concept and sense of honor, contextualizing and legitimating those power imperatives as the state's honor is maintained. In the Russian case, not only the governing elite, i.e., the governing Putin team, but also power institutions such as the Russian military and the Russian Orthodox Church (ROC), are fully committed to the Russian national idea. Moreover, the strong commitment of the ROC, with its profound and country-wide organic relationship with the Russian people, signifies a central factor in buttressing the Putin elite's national idea $^{24}$. We are not naïve in thinking that all of Russia's Eurasian neighbors would associate the notion of honor with Russian foreign and security policy actions ${ }^{25}$. But in considering a twenty first century Russian national idea that includes as a core pillar Russia's leadership role in its geostrategic space, long-held socio-cultural values that transcend the power calculations of a given moment also merit consideration. Indeed, a contemporary national idea, tied with a Russian self-concept as a Eurasian civilization, can be animated by long-held socio-cultural values that are tied with a sense of national honor.

\section{Civilization with honor}

Vladimir Putin famously remarked that the collapse of the Soviet Union was the greatest tragedy of the twentieth century ${ }^{26}$. While Westerns were perplexed, if not appalled, Russians understood Putin's observation. With the late 1991 Soviet collapse, nearly 25 million Russians found themselves living outside the political safeguards of a Russian state. Meanwhile, the world's other superpower, the United States, was left standing unconstrained and free to express its power interests as it chose, and over the next decades it certainly did so, and on continents far from the American homeland. The Soviet collapse ended a roughly five-hundred-year period of Russian power expansion and maintenance, going back to the middle of the $15^{\text {th }}$ century. Yet over those five centuries, Russian state growth and expression of power interests occurred simultaneously with the flourishing of a Russian

\footnotetext{
${ }^{24}$ See Patriarch Kirill I, «Особой национальной идеей, пронизывающей нашу историю и культуру на протяжении многих веков, является идея человеческой солидарности». Выступление Святейшего Патриарха Кирилла на открытии XVII Всемирного русского народного собора. Пресс-служба Патриарха Московского и всея Руси. 31 октября 2013 г. URL: http://www.patriarchia.ru/db/text/3334783.html. Accessed: 22.09.2021.

${ }^{25}$ E.g., during a wide-ranging exchange between one of the authors and a Finnish foreign minister of the 1990s, strong reservations were expressed over the November 1939 Soviet invasion of Finland and the launching of the Winter War, with the notion of «Russian honor» difficult to comprehend. Conversation with Dr. Keijo Korhonen, Tucson, Arizona, U.S., 10.06.20.

${ }^{26}$ URL: http://en.kremlin.ru/events/president/transcripts/22931. Accessed: 22.09.2021.
} 
national culture that also gave expression to ideas of a Russian-guided Eurasian civilization. Whether Imperial or Soviet, political-institutional norms, tied with a communalist-collectivist culture, were joined with growing economic imperatives that bound Russians together and concomitantly tied Russians with other neighboring peoples, especially Eastern Slavs and Orthodox believers. The disruption of the Marxist-Leninist model, with policies focused on class and not national interests and promoting atheism (or the replacement of a Christian with a sort of Marxist-Leninist religiosity), should not obscure the longer-term, centuries-long trend that suggested a Eurasian civilization highly influenced by Russia.

Great powers fashion their own notions of a civilization that reflects their experiences and values, and atop which they stand. This is no less true of contemporary and recent powers such as the United States and Great Britain, than it is of ancient powers such as Rome and Persia. Oftentimes challenged by regional powers such as Austria-Hungary, Germany, and Turkey, while also contending with more distant powers such as Great Britain, Russian thinkers and officials have long articulated the notion of a Russian self-concept that includes a distinctive Eurasian national-cultural entity with a civilizing mission expressed within its natural geostrategic setting. In the wake of the dramatic developments that ended Russia's centuries long power position, it is predictable that a leader and governing team striving to «pick up the pieces» and restore Russia's regional and global position would consider a new twenty first century civilizational reality. Moreover, in reflecting over the past and calculating Russia's contemporary resource base and potential, patterns of past foreign commitments and applied policies would naturally lend themselves to new notions of Russian «honor» in crafting and implementing twenty first century policies.

In recent years, a new concept - Russia as a state-civilization - has begun to gain popularity in Russia, it is actively supported by the country's top leadership and the Moscow Patriarchate. This idea has been repeatedly voiced by Vladimir Putin, he identifies himself as a «pragmatist with a conservative bias», and he emphasizes that the model of the state-civilization sets out the peculiarities of the state structure of the Russian Federation follows ${ }^{27}$. In his high-profile article «Russia: the national question», appearing in multiple setting, Putin touches upon the most acute problems of modern Russia, and indeed of the whole world, the issues of interethnic interaction, integration, migration, and socio-cultural adaptation of migrants ${ }^{28}$. Putin strongly contends that Russia has more opportunities to cope with these problems than other countries, mostly given its long history of having a multinational culture. Relatedly, the Russian President points to the strengthening of migration processes in the world, calling them a new «great migration of peoples»; he adds that there is a «failure of a multicultural project» in «the most developed and prosperous countries», where the authorities have proven unable to integrate what he terms the «foreign cultural element» into society. Drawing on its history, communalist values, and long experience in coping with interactions of different cultures, religions, ethnic groups, Putin contends Russia is well-positioned to advance a model «nation state»: «a state historically built exclusively on the basis of ethnic identity».

Space precludes a fuller development of Putin's thesis about the Russian nation state, but suffice it to note that the Russian President builds off of thinking of Vasily Klyuchevsky, among others, in emphasizing that «historical Russia is not an ethnic state - Russia arose and developed over the centuries as a multinational state» [9]. Whatever the riches of the Russian socio-cultural experience, Putin decries the idea of building an exclusively Russian national state, arguing that a mono-ethnic state contradicts Russia's entire thousand-year history. In contrast, the Russian President posits that if «the core that holds the fabric of this unique civilization is the Russian people, Russian culture», that

${ }^{27}$ URL: http://www.rbc.ru/rbcfreenews/20130904114725.shtml. Accessed: 22.09.2021.

${ }^{28}$ URL: http://www.ng.ru/politics/2012-01-23/1_national.html?print=Y. Accessed: 22.09.2021. 
civilization is multiethnic, its community is multicultural, and it is a nation state form that requires «constant dynamics, dialogue». Thus, core to this international pillar of the Russian national idea is a civilizational model wherein the Russian people, through a commitment («great mission») to unite and cement a Eurasian civilization, «fasten Russian Armenians, Russian Azerbaijanis, Russian Germans, Russian Tatars... [by means of] common culture and common values». Whether in an address to the Federal Assembly, or participation in a Valdai International Discussion Club session, Putin amplified on this theme of a Russian-led multi-ethnic, multi-confessional, civilization-state, noting the push-pull of historical forces, the advances and setbacks with external powers, but concluding with the judgement that «we are very proud of this harmony of originality and common destiny of the peoples of the Russian Federation and value it very much» ${ }^{29}$. Indeed, in a May 2020 television appearance, Putin added that new twenty first century technologies would only enhance Russia's development, not as a separate country, but as a separate civilization ${ }^{30}$.

References to civilization are quite crucial to understand the discourse of the Russian state since 2000. Then-President Dmitry Medvedev referred to Russian civilization: «I think it could hardly be otherwise when we are talking about a people with more than a thousand years of history, a people that have developed and brought civilization to a vast territory, created a unique culture and built up powerful economic and military potential, a people who act on the solid basis of values and ideals that have taken shape over the centuries and stood the test of time ${ }^{31}$. As early as his first presidency, Putin emphasized Russia's «civilizing mission» in Eurasia, and he invoked government officials, social scientists, and clergy in arguing that Russia is «a country with its own set of values, its own laws of social development, its own model of society and state, its own system of historical and spiritual

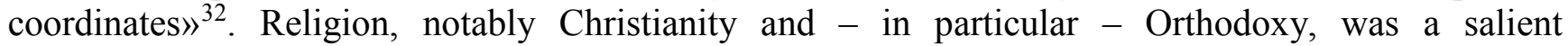
component of this civilization-state. Putin identified Christianity as «a powerful spiritual unifying force that helped involve various tribes and tribal unions of the vast Eastern Slavic world in the creation of a Russian nation and Russian state ${ }^{33}$. For the Putin team, the Russian Orthodox Church, with an allied Patriarch at its helm, constituted a powerful institutional force that advanced the interests of this civilization-state ${ }^{34}$.

Notwithstanding the posited moral imperatives, and even granting that many ethnic and religious communities peacefully coexisted for centuries, there were weaknesses with Russia advancing itself as an independent Eurasian civilization, not the least of which involved the country's economic and technological lag behind the West. Also, there was a decided demographic imbalance with China and India, which themselves constituted separate civilizations. Yet the idea that Russia constitutes a special

\footnotetext{
${ }^{29}$ URL: http://en.kremlin.ru/events/president/news/17118, accessed 27.09.2021; Vladimir Putin spoke at the final plenary session of the 16th meeting of the Valdai International Discussion Club. Official Internet Resources of the President of Russia. October 3, 2019. URL: http://en.kremlin.ru/events/president/news/61719. Accessed: 22.09.2021.

30 Putin appearance on «Russia 1» Channel, date (May 2020); Владимир Путин назвал Россию отдельной цивилизацией. URL: https://ria.ru/20200517/1571580444.html. Accessed: 22.09.2021.

${ }^{31}$ URL: http://en.kremlin.ru/events/president/news/1969. Accessed: 22.09.2021.

${ }^{32}$ URL: http://en.kremlin.ru/events/president/transcripts/22931. Accessed: 22.09.2021.

${ }^{33}$ URL: http://en.kremlin.ru/events/president/news/47173. Accessed: 22.09.2021.

${ }^{34}$ Recalling the then-recently deceased Patriarch Alexy II, Foreign Minister Sergey Lavrov observed that «it is impossible to overestimate the contribution of the Primate of the Church to strengthening the positions of our Fatherland in the world and enhancing the international prestige of Russia. His firm stand for the preservation of moral principles in politics and for the promotion of understanding between peoples and civilizations is, undoubtedly, an important part of his legacy»; Minister of Foreign Affairs of Russia, to the Holy Synod of the Russian Orthodox Church over the Death of Patriarch Alexy II of Moscow and all Russia. Ministry of Foreign Affairs. URL: http://www.mid.ru/bdomp/brp_4.nsf/e78a48070f128a7b43256999005bcbb3/e99d01ee8637c3d6c3257523003f9f6d!OpenD ocument. Accessed: 22.09.2021.
} 
community, a separate civilization, has deep historical roots that extend well beyond Putin, Medvedev and their team. Oswald Spengler, Nikolai Danilevsky, Arnold Toynbee, and others wrote about Russia as a civilization; Spengler's works on the decline of European civilization and the emergence of the United States and Russia as new civilizational centers were quite popular in Russia [23, 32, 33].

A final dimension of the notion of a Russian-led Eurasian civilization is developed through the concept of Eurasianism. Advocates of the notion of Eurasianism have believed that a third center, Eurasia, was located between Europe and Asia, having clearly delineated geographical boundaries and its own population, with the Russian people the most numerous and influential. In this school of thinking, this population's culture has elements of both Western and Eastern societies, but does constitute an absolutely unique phenomenon. One of the leading advocates of modern Eurasianism, Lev Gumilyov, has illuminated the role of civilization and cultural factors in the domestic politics of Russia, and Putin has built off Gumilyov's thinking by what he - Putin - calls a civilizational approach in international relations [4]. According to Putin, the 21st century represents an era of large «geopolitical continents», and it is a top priority for Russia to more closely integrate with neighboring countries. To achieve this goal, a Eurasian Union was proposed, as Putin put it, as «a project to preserve the identity of peoples, the historical Eurasian space in the new century and in the new world. Eurasian integration is a chance for the entire post-Soviet space to become an independent center of global development, and not a periphery for Europe or Asia» ${ }^{35}$. Meanwhile, drawing upon Gumilyov, the uniqueness of the Russian civilizational experience does not present it from adopting European values or accepting political multipolarity. Hence, for Putin, Gumilyov's combination of cultural and spiritual prophecies about the greatness of Russia made it possible to conclude that the civilizational uniqueness of Russia could become not only an internal, but also an international agenda. The terminology used in Putin's speech, for instance the historical Eurasian space, and an independent center, bears traces of Eurasianism. It is noteworthy that the Russian president sees the entire postSoviet space in the Eurasian Union. Accordingly, the Russian civilization can become a starting point for relations with neighboring countries. Thus, the international pillar of the Russian national idea includes a potential long-term unifying of peoples of the post-Soviet space, though selected initiatives beyond that space suggest an even broader vision as Russia defends the $21^{\text {st }}$ century interests of Slavs and Eastern Orthodoxy ${ }^{36}$.

\section{Final Thought}

One Western scholar has written of what he terms «the Russia anxiety», and in the seemingly eternal worry about Russian power and intentions, it is not surprising that little Western attention has been given to a twenty first century Russian national idea [43]. Indeed, if such a national idea stems from the thinking and policies of Vladimir Putin and his team, it is predictable that such a programmatic perspective is ignored, if not scorned [32]. In this article, we contend there is such a Russian national idea, the weltanschauung underlying it was succinctly laid out in a late 1999 article by the then-prime minister, with its four pillars identified and with policies stemming from them evolving over the subsequent decades. In our effort to illuminate the Putin team's national idea, we do not suggest there have not been twists and turns in the government's interests and policies, nor do we imply there have not been problems and setbacks. But in focusing on a twenty first century Russian national idea, we see the substantive grounding for a programmatic vision and implemented policies

\footnotetext{
${ }^{35}$ URL: https://rg.ru/2013/09/19/stenogramma-site.html. Accessed: 22.09.2021.

${ }^{36}$ E.g., the 2010s expansion of the Russian Orthodox Spiritual and Cultural Center in Paris, cultural linkages with countries such as Greece (high-profile May 2016 exhibit of historical icons in the Athens exhibit, «Russian Icon after the Fall of Constantinople»), and continuing Russian concerns over the spiritual sites of the Holy Land.
} 
that combined animate the federal state's further consolidation, the market economy's advances, repositioned social welfare arrangements, and a more assertive Russian Eurasian foreign policy. We conclude that Russia will need two generations, or forty years, to fully sort out the consequences of the country's dramatic transformation since the 1991 Soviet collapse. We contend that understanding the governing team's national idea is essential as we continue to interpret both the direction and consequences of Russia's ongoing transformation. The article's goal is to provide such an overview understanding. 


\section{Литература}

1. Багдасарян В.Э. Высшие ценности Российского государства. Сер. «Политическая аксиология». - Москва: Научный эксперт. 2012. 624 с.

2. Бердяев Н.А. Русская идея. Судьба России. - Москва: Искусство. 1998. 380 с.

3. Гринберг Р.С. Пятнадцать лет рыночной экономики в России // Вестн. Рос. акад. наук. 2007. - T. 77. - № 7. - С. 584-592.

4. Гумилев Л.Н. Этногенез и биосфера земли. - Москва: Айрис-пресс. 2006. 557 с.

5. Данилевский Н.Я. Россия и Европа: Взгляд на культурные и политические отношения Славянского мира к Германо-Романскому. 6-е изд. - Санкт-Петербург: Издательство С.Петербургского университета, Издательство «Глаголь». 1995. 552 с.

6. Ильин И.А. Россия есть живой организм //Русская идея. Сост. М.А. Маслин. - Москва: Наука. 1992. - C. 436-441.

7. Ильин И.А. О русской идее //Русская идея. /Сост. и авт. вступ. ст. М.А. Маслин. - Москва: Республика. 1992. 496 с.

8. Карсавин Л.П. Восток, Запад и русская, идея //Русская идея. - Москва: Республика. 1992. 105 c.

9. Ключевский В.О. Энциклопедия. /Гл. ред. С. О. Шмидт; сост.: М.И. Андреев, В.М. Карев. Москва: Большая российская энциклопедия. 1997. 976 с.

10. Леонтьев К.Н. Византизм и славянство //Леонтьев К.Н. Избранное. - Москва: "Рарогъ", "Московский рабочий". 1993. - С. 19-118.

11. Медведев В.А. Постперестроечная Россия: проблемы и перспективы. - Москва, 1999. Ч.1. Вопросы теории и методологии. 147 с.; Ч.2. Социально-экономический кризис: где же выход? $294 \mathrm{c}$.

12. Обострение демографического кризиса и современное положение России. /Под ред. Б.С. Хорева, Л.В. Иванковой. - Москва: Информпечать. 2000. 117 с.

13. Осипов Г.В. Россия: национальная идея и социальная стратегия //Вопросы философии. 1997. - № 10. - С. 13-28.

14. Панарин А.С. Россия в поисках идеи: варианты цивилизационного выбора //Вестник МГУ. Серия 12. Политические науки. - 1993. - № 5. - С. 9-16.

15. Пантин В.И. Политическая и цивилизационная самоидентификация современного российского общества в условиях глобализации //Полис. Политические исследования. - 2008. №3. - C. 29-39.

16. Пивоваров Ю.С. Русская политическая традиция и современность. - Москва: ИНИОН РАН. 2006. $256 \mathrm{c}$.

17. Реформы глазами американских и российских ученых. /Под общей редакцией академика Богомолова О.Т. - М. 1996. 130 с.

18. Савиикий П.Н. Степь и оседлость. - Москва: Худ. лит. 2003. 234 с.

19. Салмин А.М. Миф истории и история мифа. Вместо введения //Национальная идея: история, идеология, миф. - Москва: ИСР РАН. 2004. 599 с.

20. Сапрыкин B.A. Ценности социализма. Суровая диалектика формационно-цивилизационной смены и преемственности системы. - Москва: «Алгоритм». 2014. 480 с.

21. Сатаров Г.А. Россия в поисках идеи. - Москва: Известия. 1995. 132 с.

22. Соловьев В.С. Сочинения в 2-х томах - Москва: Правда. 1989. $688+736$ с.

23. Тойнби, А.Дж. Постижение истории: сб.; пер. с англ. Е.Д. Жаркова. - Москва. 2008. 640 с. 
24. Троиџкий E.C. О русской идее. Очерк теории возрождения нации. - Москва: Политиздат, 1994. $313 \mathrm{c}$.

25. Федорченко С.Н. Реконцептуализация наследия В.Л. Цымбурского: политическая легитимация в условиях цифровизации международных отношений // Журнал политических исследований. - 2021. - Т. 5. - № 2. - С. 66-86. - DOI: 10.12737/2587-6295-2021-5-2-66-86.

26. Якунин В.И., Сулакшин С.С., Багдасарян В.Э. [и др.] Национальная идея России: в 6 т. Т. 1. - Москва: Научный эксперт. 2012. 752 с.

27. Appelbaum A. Twilight of Democracy: The Seductive Lure of Authoritarianism. - NY: Doubleday. 2020. $224 \mathrm{p}$.

28. Begum A. Inter-Republican Cooperation of the Russian Republic. Ph.D. Dissertation. Department of Political Science. University of Arizona. - Tucson. USA. 1995. 225 p.

29. Belton C. Putin's People: How the KGB Took Back Russia and Then Took On the West. - N.Y.: Farrar, Strauss, and Giroux. 2020. 640 p.

30. Bennett A. Process Tracing and Causal Inference //Brady H.E. and Collier D., eds., Rethinking Social Inquiry: Diverse Tools, Shared Standards. Lanham. MD: Rowman and Littlefield, Second Edition. 2010. 384 p.

31. Billington $J$. The Icon and the Axe: An Interpretive History of Russian Culture. - N.Y.: Random House. 1970.880 p.

32. Cohen S.F. Distorting Russia//The Nation. February 11. 2014. P. 6-11.

33. Engels D. Oswald Spengler and the Decline of the West //Sedgwick, M. (ed.). Key Thinkers of the Radical Right: Behind the New Threat to Liberal Democracy. - Oxford: Oxford University Press. 2019. $352 \mathrm{p}$.

34. Gorbachev M. What is at stake now: My Appeal for Peace and Freedom. - N.Y.: Polity. 2020. 140 p.

35. Grant S.A. Obshchina and Mir //Slavic Review. - 1976. - Vol. 35. - P. 636-51.

36. Karatnycky B. The 'Nearest Abroad': Russia's Relations with Ukraine and Belarus //Ra'anan U. and Martin K., eds., Russia: A Return to Imperialism? - N.Y.: St. Martin's Press. 1995. 216 p.

37. Levitsky S., Ziblatt D. How Democracies Die. - N.Y.: Broadway Books. 2018. 320 p.

38. Matveeva A. Through Times of Trouble: Conflict in Southeastern Ukraine Explained from Within. - Lanham. Maryland: Lexington Books. 2018. 356 p.

39. Mearsheimer J.G. Why the Ukraine Crisis is the West's Fault //Foreign Affairs. September/October 2014. P. 77-83.

40. Myers S.L. The New Tsar: The Rise and Reign of Vladimir Putin. - N.Y.: Vintage. 2016. 592 p.

41. Ragsdale H. The Russian Tragedy: The Burden of History. - Armonk: M.E. Sharpe. 1996. 322 p.

42. Robinson N. Contemporary Russian Politics. - Cambridge: Polity. 2018. 304 p.

43. Smith M.B. The Russia Anxiety: And How History Can Resolve It. - Oxford: Oxford University Press. 2019. 480 p.

44. Tsygankov A.P. Russia and the West from Alexander to Putin: Honor in International Relations. Cambridge: Cambridge University Press. 2012. 330 p.

45. Tsygankov A.P. Russia's Foreign Policy: Change and Continuity in National Identity, Fifth Edition. - Lanham, Maryland: Rowman and Littlefield. 2019. 336 p.

46. Willerton J.P., Beznosov M., Carrier M. Addressing the Challenges of Russia's 'Failing State': The Legacy of Gorbachev and the Promise of Putin //Demokratizatsiya. Vol. 13. №2. Spring 2005. P. 219239. 
47. Willerton J.P. Mosca è nostra nemica perché non la capiamo //Russia, the US, and the Cold War that never ended. - Limes: Revista Italiana di Geopolitica (Limes: Italian Review of Geopolitics). March 2016. - Volume 16. - Issue 2. P. 115-122.

48. Willerton J.P. Washington chiama Mosca //Washington calls Moscow. - Limes: Revista Italiana di Geopolitica (Limes: Italian Review of Geopolitics). - November 2016. - Volume 16. - Issue 11. - P. 143-153.

49. Zygar M. All the Kremlin's Men: Inside the Court of Vladimir Putin. - N.Y.: Public Affairs. 2016. $400 \mathrm{p}$.

\section{References}

1. Bagdasaryan V.E. Vysshie cennosti Rossijskogo gosudarstva. [The highest values of the Russian state]. Ser. «Politicheskaya aksiologiya». M., Nauchnyj ekspert Publ., 2012, 624 p.

2. Berdyaev N.A. Russkaya ideya. Sud'ba Rossii [Russian idea, The destiny of Russia]. M., Iskusstvo Publ., 1998, 380 p. (In Russian).

3. Grinberg, R.S. Pyatnadcat' let rynochnoj ekonomiki v Rossii [15 years of the market economy in Russia] Vestn. Ros. akad. Nauk [Bulletin of Russian Academy of Sciences], 2007, V. 77, I. 7, pp. 584592. (In Russian).

4. Gumilev L.N. Etnogenez i biosfera zemli. M., Ajris-press Publ., 2006, 557 p. (In Russian).

5. Danilevskij, N.YA. Rossiya $i$ Evropa: Vzglyad na kul'turnye $i$ politicheskie otnosheniya Slavyanskogo mira $k$ Germano-Romanskomu. 6-e izd. SPb., Izdatel'stvo S.-Peterburgskogo universiteta, Izdatel'stvo «Glagol'» Publ., 1995, 552 p. (In Russian).

6. Il'in I.A. Rossiya est' zhivoj organizm. V kn.: Russkaya ideya [The Russian Idea]. Sost. M.A. Maslin. M., Nauka Publ., 1992, pp. 436-441. (In Russian).

7. Il'in I.A. O russkoj idee [On the Russian idea] Russkaya ideya / sost. i avt. vstup. st. M.A. Maslin. M., Respublika Publ., 1992, 496 p. (In Russian).

8. Karsavin L.P. Vostok, Zapad i russkaya ideya [East, West and the Russian idea] Russkaya ideya. M., Respublika Publ., 1992, 105 p. (In Russian).

9. Klyuchevskij V.O. Moskva: Enciklopediya [Encyclopedia] /gl. red. S. O. Shmidt; sost.: M. I. Andreev, V. M. Karev. M., Bol'shaya rossijskaya enciklopediya Publ., 1997, 976 p. (In Russian).

10. Leont'ev K.N. Vizantizm i slavyanstvo, Leont'ev K.N. Izbrannoe. M., "Rarog", "Moskovskij rabochij" Publ., 1993, pp. 19-118. (In Russian).

11. Medvedev V.A. Postperestroechnaya Rossiya: problemy i perspektivy [Post-perestroika Russia: problems and perspectives]. M. Publ., 1999. CH.1. Voprosy teorii i metodologii [Questions of theory and methodology]. 147 p.; CH.2. Social'no-ekonomicheskij krizis: gde zhe vyhod? [Socio-economic crisis: where is the way out?], 294 p. (In Russian).

12. Obostrenie demograficheskogo krizisa $i$ sovremennoe polozhenie Rossii [Aggravation of the demographic crisis and the current situation in Russia] /pod. red. B.S. Horeva, L.V. Ivankovoj. M., Informpechat' Publ., 2000, 117 p. (In Russian).

13. Osipov G.V. Rossiya: nacional'naya ideya i social'naya strategiya [Russia: national idea and social strategy] Voprosy filosofii [Philosophy questions], 1997, I. 10, p. 13-28. (In Russian).

14. Panarin A.S. Rossiya v poiskah idei: varianty civilizacionnogo vybora [Russia in search of an idea: options for a civilizational choice] Vestnik MGU. Seriya 12. Politicheskie nauki [Moscow State University Bulletin. Series 12. Political sciences]. 1993, I. 5, pp. 9-16. (In Russian).

15. Pantin V.I. Politicheskaya i civilizacionnaya samoidentifikaciya sovremennogo rossijskogo obshchestva $\mathrm{v}$ usloviyah globalizacii [Political and civilizational self-identification of modern Russian 
society in the context of globalization] Polis. Politicheskie issledovaniya [Policy. Political studies], 2008, I. 3, pp. 29-39. (In Russian).

16. Pivovarov YU.S. Russkaya politicheskaya tradiciya i sovremennost' [Russian political tradition and modernity]. M., INION RAN Publ., 2006, 256 p. (In Russian).

17. Reformy glazami amerikanskih $i$ rossijskih uchenyh [Reforms through the eyes of American and Russian scientists.]. M., 1996, 130 p. (In Russian).

18. Savickij P.N. Step' i osedlost' [Steppe and Settlement]. M., Hud. lit. Publ., 2003, 234 p. (In Russian).

19. Salmin A.M. Mif istorii i istoriya mifa. Vmesto vvedeniya [History myth and myth history. Instead of introducing] Nacional'naya ideya: istoriya, ideologiya, mif [National idea: history, ideology, myth]. M., ISR RAN Publ., 2004, 599 p. (In Russian).

20. Saprykin V.A. Cennosti socializma. Surovaya dialektika formacionno-civilizacionnoj smeny $i$ preemstvennosti sistemy [The values of socialism. Harsh dialectics of formational-civilizational change and system continuity]. M., «Algoritm» Publ., 2014, 480 p. (In Russian).

21. Satarov G.A. Rossiya v poiskah idei [Russia in search of an idea]. M., Izvestiya Publ., 1995, 132 p. (In Russian).

22. Solov'ev B.C. Sochineniya v 2-h tomah [Works in 2 volumes]. M., Pravda Publ., 1989. $688+736$ p. (In Russian).

23. Tojnbi, A.Dzh. Postizhenie istorii [A study of history]: sb.; per. s angl. E.D. Zharkova. M., 2008. 640 p. (In Russian).

24. Troickij E.S. O russkoj idee. Ocherk teorii vozrozhdeniya nacii [About the Russian idea. Essay on the theory of the revival of the nation]. M., Politizdat Publ., 1994, 313 p. (In Russian).

25. Fedorchenko S.N. Rekonceptualizaciya naslediya V.L. Cymburskogo: politicheskaya legitimaciya $\mathrm{v}$ usloviyah cifrovizacii mezhdunarodnyh otnoshenij [Reconceptualization of V.L. Tsymbursky: political legitimation in the context of digitalization of international relations] Zhurnal politicheskih issledovanij [Journal of Political Research], 2021, V. 5, I. 2, pp. 66-86, DOI: 10.12737/2587-62952021-5-2-66-86. (In Russian).

26. YAkunin V.I., Sulakshin S.S., Bagdasaryan V.E. [i dr.] Nacional'naya ideya Rossii: v 6 t. T. 1. [The national idea of Russia: in 6 volumes. Vole 1]. M., Nauchnyj ekspert Publ., 2012, 752 p. (In Russian).

27. Appelbaum A. Twilight of Democracy: The Seductive Lure of Authoritarianism, NY, Doubleday Publ., 2020, 224 p.

28. Begum A. Inter-Republican Cooperation of the Russian Republic, Ph.D. Dissertation, Department of Political Science, University of Arizona, Tucson, USA, 1995, 225 p.

29. Belton C. Putin's People: How the KGB Took Back Russia and Then Took On the West, N.Y., Farrar, Strauss, and Giroux Publ., 2020, 640 p.

30. Bennett A. Process Tracing and Causal Inference, in Brady H.E. and Collier D., eds., Rethinking Social Inquiry: Diverse Tools, Shared Standards, Lanham, MD, Rowman and Littlefield Publ., Second Edition, 2010, 384 p.

31. Billington J. The Icon and the Axe: An Interpretive History of Russian Culture, N.Y., Random House Publ., 1970, 880 p.

32. Cohen S.F. Distorting Russia, The Nation, 2014, February 11, pp. 6-11.

33. Engels D. Oswald Spengler and the Decline of the West, in Sedgwick, M. (ed.). Key Thinkers of the Radical Right: Behind the New Threat to Liberal Democracy, Oxford, Oxford University Press Publ., 2019, 352 p. 
34. Gorbachev M. What is at stake now: My Appeal for Peace and Freedom, N.Y., Polity Publ., 2020,140 p.

35. Grant S.A. Obshchina and Mir, Slavic Review, December 1976, V. 35, I. 4, pp. 636-51.

36. Karatnycky B. The 'Nearest Abroad': Russia's Relations with Ukraine and Belarus, in Ra'anan U. and Martin K., eds., Russia: A Return to Imperialism? N.Y., St. Martin's Press Publ., 1995, 216 p.

37. Levitsky S., Ziblatt D. How Democracies Die, N.Y., Broadway Books Publ., 2018, 320 p.

38. Matveeva A. Through Times of Trouble: Conflict in Southeastern Ukraine Explained from Within, Lanham, Maryland, Lexington Books, 2018, 356 p.

39. Mearsheimer J.G. Why the Ukraine Crisis is the West's Fault, Foreign Affairs, September/October 2014, pp. 77-83.

40. Myers S.L. The New Tsar: The Rise and Reign of Vladimir Putin, N.Y., Vintage Publ., 2016, 592 p.

41. Ragsdale H. The Russian Tragedy: The Burden of History, Armonk, M.E. Sharpe Publ., 1996, 322 p.

42. Robinson N. Contemporary Russian Politics, Cambridge: Polity Publ., 2018, 304 p.

43. Smith M.B. The Russia Anxiety: And How History Can Resolve It, Oxford, Oxford University Press Publ., 2019, 480 p.

44. Tsygankov A.P. Russia and the West from Alexander to Putin: Honor in International Relations, Cambridge, Cambridge University Press Publ., 2012, 330 p.

45. Tsygankov A.P. Russia's Foreign Policy: Change and Continuity in National Identity, Fifth Edition, Lanham, Maryland: Rowman and Littlefield Publ., 2019, 336 p.

46. Willerton J.P., Beznosov M., Carrier M. Addressing the Challenges of Russia's 'Failing State': The Legacy of Gorbachev and the Promise of Putin, Demokratizatsiya, Spring 2005, V. 13, I. 2, pp. 219 39.

47. Willerton J.P. Mosca è nostra nemica perché non la capiamo (Russia, the US, and the Cold War that never ended), Limes: Revista Italiana di Geopolitica (Limes: Italian Review of Geopolitics), 2016, Volume 16, Issue 2, pp. 115-22.

48. Willerton J.P. Washington chiama Mosca (Washington calls Moscow), Limes: Revista Italiana di Geopolitica (Limes: Italian Review of Geopolitics), November 2016, Volume 16, Issue 11, pp. 143-53. 49. Zygar M. All the Kremlin's Men: Inside the Court of Vladimir Putin, N.Y., Public Affairs Publ., 2016, 400 p. 